\title{
PERKAWINAN DINI DAN PERMASALAHANNYA (Studi Kasus Kelurahan Tataaran 2 Kecamatan Tondano Selatan Kabupaten Minahasa)
}

Oleh:

Imelda M. Turangan, Apeles L. Lonto, Julien Biringan Jurusan PPKn FIS Unima

Email: lexi.lonto@unima.ac.id

\begin{abstract}
ABSTRAK
Penelitian tentang perkawinan dini dan permasalahannya di Kelurahan Tataaran 2 Kecamatan Tondano Selatan Kabupaten Minahasa. Adapun masalah yang terjadi dilapangan yaitu masih banyak terjadi perkawinan dini yang disebabkan karena hamil pranikah yang diakibatkan karena pergaulan yang terlalu bebas. Adapun teori yang mendukung dalam penelitian ini adalah teori tentang perkawinan, dan perkawinan dibawah umur. Metode penelitian yang digunakan dalam penelitian ini yakni menggunakan pendekatan kualitatif. Dalam penelitian ini, data yang digunakan adalah data primer berupa wawancara mendalam kepada pasangan-pasangan suami-isteri yang melakukan perkawinan dini di Kelurahan Tataaran 2, dan data sekunder yaitu data pelengkap dari pemerintah, dengan teknik pengumpulan data menggunakan pedoman wawancara dan triangulasi. Selanjutnya teknik analisis data dari penelitian ini dikelola dengan cara kualitatif. Hasil temuan dalam penelitian menunjukkan bahwa pemahaman masyarakat yang ada di Kelurahan Tataaran 2 mengenai perkawinan dibawah umur dan perkawinan yang memenuhi syarat/ketentuan dipandang sama. Perkawinan dini yang terjadi di Kelurahan Tataaran 2 disebabkan karena pergaulan yang terlalu bebas dan menikah karena sudah hamil pranikah, serta sering terjadi percekcokkan/pertengkaran dalam kehidupan berumah tangga oleh para pasangan muda.
\end{abstract}

\section{Kata Kunci: Perkawinan, Perkawinan Dini}




\section{PENDAHULUAN}

Perkawinan merupakan suatu ikatan yang melahirkan keluarga sebagai salah satu unsur dalam kehidupan bermasyarakat dan bernegara yang diatur oleh hukum. Adanya perundangan tentang perkawinan dengan tujuan supaya peristiwa hukum yaitu perkawinan dapat menjamin ketertiban dalam masyarakat. Perkawinan sangat penting untuk mengatur kehidupan rumah tangga dan keturunan, tanpa perkawinan tidak mungkin laki-laki dan perempuan dapat membentuk dan mengatur rumah tangga secara tertib dan teratur.

Selanjutnya perkawinan menurut Undang-Undang No 1 Tahun 1974 adalah pasal 1 yaitu Perkawinan adalah ikatan lahir batin antara seorang pria dan seorang wanita sebagai suami istri dengan tujuan membentuk keluarga atau rumah tangga yang bahagia dan kekal berdasarkan Ketuhanan Yang Maha Esa. Dengan dilangsungkannya perkawinan maka status sosialnya dalam kehidupan bermasyarakat diakui sebagai pasangan suami-istri, dan sah secara hukum dan agama. Selain itu juga seseorang dengan melangsungkan sebuah perkawinan maka dengan sendirinya semua kebutuhan biologisnya bisa terpenuhi.

Pada dasarnya perkawinan secara umum dilakukan oleh orang dewasa dengan tidak memandang pada profesi, agama, suku bangsa, miskin atau kaya, tinggal di desa atau di kota. Namun tidak sedikit manusia yang sudah mempunyai kemampuan baik fisik maupun mental akan mencari pasangannya sesuai dengan apa yang diinginkannya. Dalam kehidupan manusia, perkawinan bukanlah bersifat sementara tetapi untuk seumur hidup. Sayangnya sebagian orang tidak bisa memahami tujuan dari perkawinan yang seutuhnya yaitu untuk mendapatkan kebahagiaan yang sejati dalam berumah tangga.
Sejak terbentuknya Undang-Undang Perkawinan sampai saat ini, kenyataannya kehidupan masyarakat menunjukan bahwa masih banyak terjadi perkawinan dini, yakni perkawinan yang dilakukan oleh pasangan yang salah satunya, atau keduanya berusia belum cukup umur padahal perkawinan yang sukses pasti membutuhkan kedewasaan tanggung jawab secara fisik maupun mental, untuk bisa mewujudkan harapan yang ideal dalam kehidupan berumah tangga. Sebagaimana dipersyaratkan oleh Undang-Undang No 1 Tahun 1974 pasal 6 (2) yaitu seseorang yang belum mencapai umur 21 tahun harus mendapat izin dari kedua orang tua.

Berdasarkan kajian-kajian di atas, apabila mencermati fenomena berdasarkan hasil prasurvey ada beberapa pasangan suami-istri yang melakukan perkawinan dini di Kelurahan Tataaran 2, yakni ada sepuluh pasangan keluarga dalam kurun waktu lima tahun terakhir yaitu dari tahun 2012 sampai dengan tahun 2016 yang umurnya kira-kira antara 15-19 tahun. Di antara kesepuluh pasangan keluarga tersebut, ada empat pasangan keluarga yakni sekitar $40 \%$ di antaranya yang telah berpisah/bercerai, dan $60 \%$ lainnya masih hidup bersama sebagai pasangan suami isteri, namun sebagian besar masih tinggal bersama dengan orang tua karena belum memiliki tempat tinggal sendiri dikarenakan tidak memiliki penghasilan yang cukup dan pekerjaan yang tetap. Namun tidak bisa dipungkiri bahwa ternyata kasus perceraian juga bisa dialami oleh para pasangan suami isteri yang menikah di usia yang sudah dewasa, tetapi tingkatannya lebih rendah di bandingkan dengan kasus perceraian yang terjadi di kalangan para pasangan yang melakukan perkawinan dini. Perkawinan dini yang terjadi di Kelurahan Tataaran 2 sebagian besar terjadi karena faktor pergaulan bebas yang mengakibatkan hamil pra nikah, serta kurangnya pemahaman masyarakat mengenai perkawinan di bawah umur. 
Sebagaimana dinyatakan dalam pasal 7 UU No. 1 Tahun 1974 bahwa "perkawinan dini dilakukan ketika seseorang baik laki-laki atau perempuan yang belum mencapai undang usia minimal untuk suatu perkawinan, yakni 16 tahun untuk wanita dan 19 tahun untuk pria”.

Perkawinan dini yang terjadi di

Kelurahan Tataaran 2 dapat mengakibatkan meningkatnya kasus perceraian karena kurangnya kesadaran untuk bertanggung jawab dalam kehidupan berumah tangga bagi suami istri, dapat menimbulkan pertengkaran dan percekcokan antara suami istri walau hanya karena masalah-masalah sepele, dan bahkan dapat mengganggu ketentraman masyarakat akibat pertengkaran tersebut, sehingga masyarakat yang merasa terganggu beberapa diantaranya dengan berani mau menegur pasangan suami-istri yang bertengkar tersebut.

Dengan demikian, berdasarkan uraian di atas maka saya tertarik untuk melakukan penelitian dengan judul: "Perkawinan Dini dan Permasalahannya (Studi Kasus di Kelurahan Tataaran 2 Kec. Tondano Selatan Kab. Minahasa)".

Berdasarkan latar belakang masalah yang sudah dikemukakan di atas, maka masalah dalam penelitian ini adalah:

1. Kurangnya pemahaman masyarakat mengenai perkawinan di bawah umur

2. Terjadi perceraian antar suami istri diusia perkawinan 1-2 tahun

3. Terjadi pertengkaran dan percekcokan antar suami isteri

4. Mengganggu ketentraman masyarakat karena perkelahian suami isteri muda

Berdasarkan identifikasi masalah yang dikemukakan di atas, maka yang menjadi rumusan masalah dalam penelitian ini adalah:

Bagaimanakah Perkawinan Dini dan permasalahannya di Kelurahan Tataaran 2 Kecamatan Tondano Selatan Kabupaten Minahasa.

\section{TINJAUAN TEORI \\ Pengertian Perkawinan}

Kansil mengungkapkan bahwa perkawinan adalah suatu hubungan antara seorang wanita dan pria yang bersifat abadi (Kansil dan Kansil, 2011:446). Dari definisi ini lebih menekankan bahwa adanya hubungan yang bersifat abadi, bisa digambarkan bahwa hubungan abadi ini menunjukan adanya saling tanggung jawab antara keduanya bahkan pula tanggung jawab pada anak yang akan lahir atau pula sebaliknya, tanggung jawab anak terhadap orang tua, ketika orang tua sudah lanjut usia.

\section{Perkawinan Menurut UU No 1 Tahun 1974}

Di dalam UU No 1 tahun 1974 tentang perkawinan pada bab 1 "Dasar Perkawinan" pasal 1 menyatakan bahwa perkawinan ialah ikatan lahir batin antara seorang pria dengan seorang wanita sebagai suami isteri dengan tujuan membentuk keluarga atau rumah tangga yang bahagia dan kekal berdasarkan Ketuhanan Yang Maha Esa. Bagi pasangan yang akan melangsungkan perkawinan seharusnya memperhatikan aturan UndangUndang No 1 tahun 1974. Karena aturan ini adalah acuan atau dasar dari setiap aturan perkawinan lainnya.

\section{Pengertian Perkawinan Di Bawah umur}

Dalam undang-undang perkawinan yakni dalam pasal 7 UU No 1 tahun 1974, dijelaskan bahwa perkawinan dini dilakukan ketika seseorang, baik laki-laki atau perempuan yang belum mencapai undang usia minimal untuk suatu perkawinan, yakni 16 tahun untuk wanita dan 19 tahun pada pria.

\section{Syarat-syarat Perkawinan Menurut UU No 1 Tahun 1974}

Dalam UU No 1 tahun 1974 pada bab 2 menegaskan tentang syarat-syarat perkawinan sebagai berikut: 
a. Sepakat para pihak dalam perkawinan

Sebagai suatu hubungan hukum yang melibatkan pihak-pihak, perkawinan diawali dengan persetujuan dari calon mempelai sebelum naik ke pelaminan. Hal ini dapat dilihat pada Pasal 6 UU Perkawinan. (H. Moch. Isnaeni, 2016:49). Jadi perkawinan tidak boleh ada unsur paksaan dari siapapun.

b. Batas usia minimum untuk kawin

Guna mengeliminir maraknya perkawinan anak-anak, dalam Pasal 7 UU Perkawinan ditetapkan bahwa usia minimum untuk kawin bagi seorang anak perempuan adalah 16 (enam belas) tahun, sedang bagi pria adalah 19 (Sembilan belas) tahun. (H. Moch. Isnaeni, 2016:53). Ini dimaksudkan untuk menjaga kesehatan suami dan istri dan keturunan, maka perlu untuk ditetapkannya batas-batas umur untuk perkawinan. Memperhatikan kematangan fisik dan biologis itu sangatlah penting bagi kedua mempelai agar tidak terjadi hal-hal seperti perceraian dan lain sebagainya.

c. Jenis halangan untuk kawin

Dalam Pasal 8 UU Perkawinan mengatur tentang larangan kawin bagi mereka yang masih memiliki hubungan darah. Sedangkan Pasal 9 UU Perkawinan menegaskan bahwa seorang yang masih terikat tali perkawinan dengan orang lain tidak dapat kawin lagi. Selanjutnya Pasal 10 UU Perkawinan melarang adanya pengulangan kawin bagi pasangan yang sama untuk beberapa kali, dengan tetap memperhatikan aturan agama yang bersangkutan. (H. Moch. Isnaeni, 2016:58) d. Jangka waktu tunggu bagi janda

Aturan selanjutnya menangani jangka waktu tunggu bagi seorang wanita yang pernah kawin, berarti yang bersangkutan berstatus janda. Ketentuan yang dimaksud dapat disimak pada Pasal 11 UU Perkawinan yang menyatakan:

1. Bagi seorang wanita yang putus perkawinannya berlaku janda waktu tunggu.
2. Tenggang waktu jangka waktu tunggu tersebut ayat (1) akan diatur dalam Peraturan Pemerintah lebih lanjut. (H. Moch. Isnaeni, 2016:60).

\section{Faktor-faktor Yang Mendorong Untuk Melangsungkan Perkawinan Muda}

Terjadinya perkawinan usia muda menurut Hollean dalam Suryono disebabkan oleh:

1. Masalah ekonomi keluarga

2. Orang tua dari gadis meminta masyarakat kepada keluarga laki-laki apabila mau mengawinkan anak gadisnya.

3. Bahwa dengan adanya perkawinan anak-anak tersebut, maka dalam keluarga gadis akan berkurang satu anggota keluarganyya yang menjadi tanggung jawab (makanan, pakaian, pendidikan, dan sebagainya) (Soekanto, 1992:65).

Selain menurut para ahli diatas ada beberapa faktor yang mendorong terjadinya perkawinan usia muda yang sering dijumpai dilingkungan masyarakat yaitu :

1. Ekonomi

Perkawinan usia muda terjadi karena keadaan keluarga yang hidup di garis kemiskinan, untuk meringankan beban orang tuanya maka anak wanitanya dikawinkan dengan orang yang dianggap mampu.

2. Pendidikan

Rendahnya tingkat pendidikan maupun pengetahuan orang tua, anak dan masyarakat menyebabkan adanya kecenderungan mengawinkan anaknya yang masih dibawah umur.

3. Faktor orang tua

Orang tua khawatir kena aib karena anak perempuannya berpacaran dengan laki-laki yang sangat lengket sehingga segera mengawinkan anaknya.

4. Media massa 
Gencarnya ekspos seks di media massa menyebabkan remaja modern kian permisif terhadap seks.

5. Faktor adat

Perkawinan usia muda terjadi karena orang tuanya takut anaknya dikatakan perawan tua sehingga segera dikawinkan.

\section{Dampak Negatif Perkawinan Usia Muda}

Den Bawonse (Skripsi tahun 2012 : 24) Dampak perkawinan usia muda akan menimbulkan hak dan kewajiban diantara kedua belah pihak, baik dalam hubungannya dengan mereka sendiri, terhadap anak-anak, maupun terhadap keluarga mereka masing-masing.

1. Dampak negatif terhadap suami isteri

Tidak bisa dipungkiri bahwa pada pasangan suami isteri yang telah melangsungkan perkawinan usia muda tidak bisa memenuhi atau tidak mengetahui hak dan kewajibannya sebagai suami isteri. Hal tersebut timbul dikarenakan belum matangnya fisik maupun mental mereka yang cenderung keduannya memiliki sifat keegoisanyang tinggi.

2. Dampak negatif terhadap anak-anaknya

Masyarakat yang telah melangsungkan perkawinan pada usia muda atau di bawah umur akan membawa dampak. Selain berdampak pada pasangan yang melangsungkan perkawinan pada usia muda, perkawinan usia muda juga berdampak pada anak-anaknya. Karena bagi wanita yang melangsungkan perkawinan di bawah usia 20 tahun, bila hamil akan mengalami gangguangangguan pada kandungannya dan banyak juga dari mereka yang melahirkan anak yang mengalami gangguan fisik.

\section{Dampak terhadap masing-masing keluarga}

Selain berdampak pada pasangan suami isteri dan anak-anaknya perkawinan di usia muda juga akan membawa dampak terhadap masing-masing keluarganya. Apabila perkawinan diantara anak-anak mereka lancar, sudah tentu akan menguntngkan orangtuanya masingmasing. Namun apabila seballiknya keadaan rumah tangga mereka tidak bahagia dan akhirnya yang terjadi adalah perceraian. Hal ini akan mengakibatkan bertambahnya biaya hidup mereka dan yang paling parah lagi akan memutuskan tali kekeluargaan di antara kedua belah pihak.

\section{METODOLOGI PENELITIAN}

Dalam penelitian ini menggunakan pendekatan kualitatif, karena dalam penelitian ini menyebutkan dan menjelaskan pemahaman tentang perkawinan dini, serta dampak dari perkawinan dini. Menurut Sugiono (2012), pada dasarnya metode penelitian merupakan cara ilmiah untuk mendapatkan data dengan tujuan dan kegunaan tertentu. Berdasarkan hal tersebut terdapat empat kata kunci yang perlu diperhatikan, yaitu cara ilmiah, data, tujuan, dan kegunaan. Cara ilmiah berarti kegiatan penelitian itu didasarkan pada ciri-ciri keilmuan, yaitu rasional, empiris, dan sistematis.

Lokasi penelitian ini di laksanakan di Kelurahan Tataaran 2 Kecamatan Tondano Selatan Kabupaten Minahasa.

Peneliti memilih lokasi penelitian di Kelurahan Tataaran 2 karena lokasi ini merupakan tempat tinggal/kampung halaman dari penulis, dimana kasus perkawinan dini di lokasi tersebut masih sering terjadi.

Waktu penelitian dalam penelitian ini akan dilaksanakan selama 3 (tiga) bulan. Adapun yang menjadi sumber data dalam penelitian ini adalah:

1. Data primer, yaitu data yang diperoleh secara langsung dilapangan, berupa wawancara mendalam kepada pasanganpasangan suami-istri yang melakukan perkawinan dini.

2. Data sekunder, yaitu data pelengkap dari pemerintah dan dokumentasi.

Instrumen dalam penelitian ini atau alat peneliti adalah peneliti itu sendiri 
sebagai instrumen yang langsung berhadapan dengan subjek-subjek yang diteliti dan tidak dapat digantikan oleh orang lain.

Guna memperoleh data yang valid dan sesuai dengan kenyataan yang terjadi di perlukan teknik pengumpulan data yang sesuai. Maka dalam penelitian ini penulis menggunakan pedoman wawancara, observasi dan triangulasi.

Selanjutnya data yang telah diperoleh akan dilakukan analisis kualitatif dengan model analisis data interaktif dari Miles dan Huberman dalam penelitian kualitataif dengan model analisis data interaktif.

\section{PEMBAHASAN HASIL PENELITIAN}

Pada bagian ini akan dianalisis sehubungan dengan "Perkawinan Dini dan permasalahannya, Studi Kasus di Kelurahan Tataaran 2 Kecamatan Tondano Selatan Kabupaten Minahasa" sebagai hasil, dan difokuskan pada beberapa indikator yakni: (1). Pemahaman masyarakat tentang perkawinan dini; (2). Keberlangsungan perkawinan; (3). Dampak perkawinan dini.

Untuk mengetahui keadaan keluarga/rumah tangga yang terbentuk melalui perkawinan dini yang terjadi dikelurahan Tataaran 2 Kecamatan Tondano Selatan, peneliti hendak mengumpulkan data melalui wawancara mendalam dengan berbagai pertanyaan kepada para informan dalam kehidupan keluarga yang terbentuk melalui perkawinan dini.

Berdasarkan hasil analisis data diatas, maka pada bagian ini akan dibahas sesuai dengan permasalahan peneliti yang difokuskan pada beberapa indikator yakni: (1). Pemahaman masyarakat tentang perkawinan dini; (2). Keberlangsungan perkawinan; (3). Dampak perkawinan dini.

\section{Pemahaman Masyarakat Tentang Perkawinan Dini}

Menurut Undang-Undang No 1 tahun 1974 perkawinan adalah ikatan lahir batin antara seorang pria dengan seorang wanita sebagai suami istri dengan tujuan membentuk keluarga atau rumah tangga yang bahagia dan kekal berdasarkan Ketuhanan Yang Maha Esa. Definisi yang dikemukakan diatas menekankan bahwa perkawinan bukan hanya ikatan fisik semata tapi juga secara batinia dan tujuannya jelas bahwa membentuk keluarga yang bahagia dan kekal berdasarkan Ketuhanan Yang Maha Esa. Pemahaman masyarakat mengenai perkawinan yang memenuhi syarat/ketentuan dipandang sama, karena mereka berpendapat bahwa perkawinan baik muda ataupun tua/dewasa adalah sah dalam hubungan berumah tangga, mereka beranggapan bahwa yang terpenting adalah perkawinan tersebut dicatat di kantor pencatatan sipil. Berdasarkan pernyataan yang dipaparkan oleh para informan, maka dapat di katakana bahwa masyarakat kurang memiliki pemahaman mengenai perkawinan di bawah umur, dan hasil penelitian ini berkaitan dengan hasil penelitian yang dilakukan oleh Zulkifly Ahmad/104054102134 dengan judul penelitian "Dampak Sosial Perkawinan Usia Dini Studi Kasus di Desa Gunung Sindur-Bogor" dengan hasil penelitian bahwa sangat terbatasnya pengetahuan masyarakat tentang pernikahan usia dini disebabkan mereka hanyalah lulusan sekolah dasar dan sekolah menengah pertama. Pada dasarnya suatu perkawinan harus dicatat sebagaimana diatur dalam Pasal 2 ayat 2 UU No. 1 Tahun 1974 yang menyatakan bahwa "tiap-tiap perkawinan dicatat menurut peraturan perundangundangan yang berlaku". Yang dimaksud dengan peraturan perundang-undangan yang berlaku adalah Peraturan Pemerintah Republik Indonesia No. 9 Tahun 1975 lebih spesifiknya tercantum pada BAB II 
Pasal 2 sampai dengan pasal 9 yang menyangkut tentang pencatatan perkawinan. Pada Pasal 2 ayat 2 PP N0. 9 Tahun 1975 menyebutkan bahwa "Pencatatan perkawinan dari mereka yang melangsungkan perkawinannya menurut agamannya dan kepercayaannya itu selain agama islam, dilakukan oleh pegawai pencatatan perkawinan pada kantor catatan sipil sebagaimana dimaksud dalam berbagai perundang-undangan mengenai pencatatan perkawinan". Jadi apabilah suatu perkawinan tidak berdasarkan dengan ketentuan ini maka perkawinan tersebut dinyatakan tidak sah. Dalam melangsungkan suatu perkawinan, seseorang yang belum mencapai umur 21 tahun harus mendapat izin dari kedua orang tua sebagaimana yang di catat dalam Pasal 6 ayat 2 UU No 1 Tahun 1974. Artinya jika kedua pasangan nekad ingin melangsungkan perkawinan tetapi tidak mendapat izin dari kedua orang tua, maka Pastor tidak boleh memberkati atau menikahkan mereka, melainkan Pastor akan mengingatkan kedua calon agar menaati dan mengikuti nasehat dari orang tuanya dengan menunda atau tidak melangsungkan pernikahan. Gereja tidak melarang para remaja untuk menikah pada usia muda, akan tetapi mereka harus terlebih dahulu meminta persetujuan dan nasehat dari orang tua, selain karena rasa hormat juga karena nasehat dari orang tua sangatlah di butuhkan bagi mereka untuk memasuki kehidupan berumah tangga. Sebagaimana yang tercantum dalam Pasal 7 UU No. 1 Tahun 1974 yang menegaskan bahwa "perkawinan hanya diizinkan jika pihak pria mencapai umur 19 tahun dan pihak perempuan sudah mencapai 16 tahun" dan pasal ini juga menurut Prof. Dr. H. Moch. Isnaeni, SH., MS adalah salah satu prinsip dalam UU No. 1 Tahun 1974. Namun berbeda halnya dengan apa yang terjadi dilapangan, sebagaimana jawabanjawaban yang diberikan oleh para informan dimana dari antara sepuluh pasangan keluarga sebagian besar menikah diusia dini yakni dibawah usia 16 tahun, dan salah satu faktor penyebabnya adalah karena hamil diluar nikah.

\section{Keberlangsungan Perkawinan}

Menurut Hadikusuma, perkawinan adalah perbuatan yang suci (sakramen, samskara), yaitu suatu perikatan antara dua pihak dalam memenuhi perintah dan anjuran Tuhan Yang Maha Esa, agar kehidupan berkeluarga dan berumah tangga serta berkerabat tetangga berjalan dengan baik sesuai dengan ajaran agama masing-masing. Dilihat dari berbagai aspek masalah dan berbagai informasi yang penulis dapatkan dilapangan, keberlangsungan perkawinan oleh beberapa pasangan muda diatas sangatlah memprihatinkan. Pasalanya terdapat beberapa pasangan muda yang usia perkawinannya hanya bertahan selama 1-2 tahun dan juga ada yang hanya bertahan selama 4 tahun saja, dan alasan mereka memilih untuk berpisah/bercerai adalah karena sering berbeda pendapat dan juga karena terlalu seringnya bertengkar sehingga mereka merasa sudah tidak cocok lagi satu sama lain. Dalam menjalin hubungan berumah tangga pasanganpasangan muda diatas semuanya sudah memiliki anak, ada yang memiliki 1 orang anak dan ada juga yang sudah memiliki 2 orang anak. Selama menjalani hubungan berumah tangga, pasangan-pasangan muda diatas menyatakan bahwa terkadang mereka merasa tidak terlalu bahagia karena seringnya cekcok dengan pasangannya, namun ada juga yang mengatakan bahwa mereka merasa bahagia karena sama-sama saling menjaga kepercayaan satu sama lain.

\section{Dampak Perkawinan Dini}

Dalam menjalani kehidupan berumah tangga, tidak jarang perkawinan dini dapat menimbulkan dampak negatif bagi pasangan-pasangan muda tersebut, hal ini 
dapat digambarkan melalui jawaban dari para informan-informan diatas dimana diantaranya ada beberapa pasangan yang harus berpisah/bercerai diakibatkan karena sering berbeda pendapat dan ada juga yang diakibatkan karena seringnya terjadi pertengakaran diantara mereka, dampak negatif selanjutnya adalah terdapat beberapa pasangan yang biaya kehidupan rumah tangganya masih harus ditanggung oleh orang tua karena kepala keluarga dari pasangan muda tersebut sulit mendapatkan pekerjaan sehingga tidak memiliki pekerjaan tetap yang mengakibatkan kepala keluarga dari pasangan muda tersebut tidak mampu untuk membiayai rumah tangga sepenuhnya sehingga orang tua harus campur tangan untuk menopang kehidupan keluarga mereka, selain itu juga akibat dari perkawinan dini adalah sering terjadinya percekcokan antara pasangan muda tersebut, hal ini dapat digambarkan melalui jawaban dari para informan diatas yang mengatakan bahwa mereka sering cekcok atau sering bertengkar karena saling cemburu, sering berbeda pendapat, dan ada juga yang sering bertengkar karena sang suami yang sering mabuk-mabukkan sehingga terkadang percekcokkan atau keributan yang terjadi selalu didengar oleh tetangga-tetangga dari pasangan keluarga tersebut sehingga lewat pertengkaran itu yang menjadi korban adalah sang isteri dimana sang suami selalu menghina dan bahkan sampai memukul isterinya, sekalipun pasangan suami isteri ini masih berstatus tinggal sementara dirumah keluarga sang isteri tapi kenyataannya sang suami tidak peduli walaupun keluarga dan para tetangga mendengar bahkan melihat kejadian tersebut. Hasil penelitian ini juga berkaitan dengan hasil penelitian yang dilakukan oleh Rusmini/E41111004 dengan judul penelitian "Dampak Menikah Dini di Kalangan Perempuan di Desa Batulappa Kecamatan Batulappa Kabupaten Pinrang (Studi Kasus Khususnya yang Menikah Dini di Dusun
Tarokko)", dengan hasil penelitian bahwa dampak yang bisa di timbulkan oleh pernikahan di usia dini yaitu adanya tindakan kekerasan yang diakibatkan karena tidak adanya persiapan serta kesiapan dalam membina rumah tangga, serta tidak adanya keseimbangan antara peran orang tua terhadap tumbuh kembang anak, sehingga timbullah keegoisan yang berujung pada pertengkaran dan melibatkan orang tua, sehingga bisa saja terjadi kerenggangan antara dua keluarga. Pada dasarnya setelah menikah sudah terikat dengan yang namanya hak dan kewajiban suami isteri sebagaimana yang ditegaskan dalam UU No. 1 Tahun 1974 Pasal 30 sampai dengan Pasal 34. Melihat dari apa yang dinyatakan dari para informan dimana kewajiban kepala keluarga tidak dipenuhi dengan sebaikbaiknya, hal ini justru bertentangan dengan Pasal 34 ayat (1) UU No. 1 Tahun 1974 yang mengatakan bahwa "suami wajib melindungi isterinya dan memberikan segala sesuatu keperluan hidup berumah tangga sesuai dengan kemampuannya”.

\section{KESIMPULAN DAN SARAN \\ Kesimpulan}

Melalui temuan penelitian data maka dapatlah ditarik beberapa kesimpulan sebagai berikut:

1. Pemahaman masyarakat yang ada di Kelurahan Tataaran 2 mengenai perkawinan yang memenuhi syarat/ketentuan dipandang sama, karena menurut mereka perkawinan baik muda atapun tua/dewasa adalah sah yang terpenting perkawinan tersebut dicatat dikantor pencatatan sipil.

2. Perkawinan dini yang terjadi di Kelurahan Tataaran 2 sebagian besar dilakukan oleh pasangan-pasangan yang berusia dibawah 16 tahun.

3. Perkawinan dini yang terjadi di Kelurahan Tataaran 2 disebabkan karena pergaulan yang terlalu bebas dan menikah karena sudah hamil pranikah. 
4. Kepala keluarga jarang membiayai kehidupan berumah tangga karena tidak memiliki pekerjaan tetap.

5. Meningkatnya kasus perceraian yang diakibatkan oleh pasangan-pasangan muda yang menikah dibawah umur.

6. Terjadi percekcokkan/pertengkaran dalam kehidupan berumah tangga oleh para pasangan muda.

\section{Saran}

1. Bagi pemerintah

Pemerintah hendaknya lebih meningkatkan dan mempertegas hukum perkawinan yang telah ditetapkan dalam UU No. 1 Tahun 1974 baik melalui penyuluhan ataupun mensosialisasikan mengenai UU perkawinan tersebut karena masih banyak masyarakat yang belum mengetahui tentang aturan tersebut.

2. Bagi orang tua

Orang tua diharapkan dapat lebih tegas lagi dalam mendidik, mengarahkan, memperhatikan serta harus mampu mengawasi anak-anak dalam pergaulan mereka.

3. Bagi remaja

Diharapkan agar supaya para remaja dapat bergaul dengan cara pergaulan yang baik, sehingga tidak merusak masa depan yang hanya merugikan diri sendiri.

\section{DAFTAR PUSTAKA}

Undang-Undang No. 1 Tahun 1974 Pasal 1, 2 (1), 2 (2), 3 (1), 6 (2), 7, 34 (1).

Peraturan Pemerintah Republik Indonesia No. 9 Tahun 1975 Pasal 2 (2).

Kansil C. S. T. - Kansil Christine, Pengantar Ilmu Hukum Indonesia, PT. Rineka Cipta, Jakarta, 2011.

R. Abdoel Djamali, Pengantar Hukum Indonesia, PT RajaGrafindo Persada, Jakarta, 2014 Hadikusuma H Hilman, Hukum Perkawinan Indonesia, Menurut Perundang-Undangan, Hukum Adat, Hukum Agama, CV. Mandar Maju, Bandung, 2007.

Witanto Y. D, Hukum Keluarga Hak Dan Kedudukan Anak Luar Kawin Pasca Keluarnya Putusan MK Tentang Uji Materi UU Perkawinan, Prestasi Pustakarya, Jakarta, 2012

H. Moch. Isnaeni, Hukum Perkawinan Indonesia, PT Refika Aditama, Bandung 2016.

Sugiono, Metode Penelitian Pendidikan (Pendekatan Kuantitatif, Kualitatif, dan R\&B), Alfabeta, Bandung, 2012.

Titik Triwulan Tutik, Hukum Perdata Dalam Sistem Hukum Nasional, Kencana, Jakarta 2008

H. Ishaq, Pengantar Hukum Indonesia (PHI), PT Rajagrafindo Persada, Jakarta 2016

Sarwono W. Sarlito, Psikologi Remaja, PT. Rajagrafindo Persada, Jakarta, 2013

Setiady Tolib, Intisari Hukum Adat Indonesia, Alfabeta, Bandung, 2008

Den Bawonse, Skripsi : Kesadaran Hukum Masyarakat Terhadap UU No. 1 Tahun 1974

Tentang Perkawinan (Suatu Studi Tentang Perkawinan Usia Muda di Desa Ammat

Selatan Kec. Tampan Amma Kab. Kepulauan Talaud), Tahun 2012.

Soejono Soekanto, 1981, Suatu Tinjauan Sosiologi dan Hukum Terhadap Masalah-Masalah Sosial, Alumni, Bandung.

Marhiyanto, Khalilah (2000), Romantika Perkawinan, Jawa Timur:Putra Pelajar.

Wiryono. (1978) Pernikahan Adalah Hidup Bersama Laki-Laki Dan Perempuan.

Yokyakarta: Media Abadi.

http://www.psychologymania.com/2012/06/pengertian-pernikahan-dini.html (diakses pada $\operatorname{tgl} 24$ juni 2017, pkl 20:34 wita) 